\title{
Improving Quality of Information on Local Financial Statements and its Utilization for Capital Expenditure Budgeting (Case Study at the Provincial Government of East Nusa Tenggara)
}

\author{
Jifvy Magdalena Dina Paomey \\ Magister of Accounting, Faculty of Economics and Business \\ Universitas Indonesia \\ Indonesia \\ jifvy_paomey@yahoo.com
}

\author{
Bambang Pamungkas \\ Magister of Accounting, Faculty of Economics and Business \\ Universitas Indonesia \\ Indonesia \\ pamungkas62@yahoo.com
}

\begin{abstract}
This thesis aims to analyze the information quality of Local Government Financial Statement (LGFS) of The Provincial Government of East Nusa Tenggara before and after the implementation of the accrual basis, the efforts of the The Provincial Government of East Nusa Tenggara to improve the quality of LGFS and the LGFS utilization design as material for policy decisions on capital expenditure and fixed assets. This study uses the basis of agency theory and operationalizes the qualitative characteristics of financial statements that are adjusted to government accounting standards in Indonesia. This research method is qualitative method with explanatory-descriptive case study. The results of LGFS information quality research in The Provincial Government of East Nusa Tenggara are at a moderate level, which means that the LGFS information is sufficient to be used in decision making. Efforts made by the Provincial Government of East Nusa Tenggara are increasing commitment to accounting policies, increasing human resource capacity and improving information systems. Furthermore, in designing the utilization of LGFS information for capital expenditure decision making, a fixed asset needs planning SOP is prepared based on the documents and related parties as well as the output produced in the draft of local government budget. There are several limitations of this research. First there is a possibility of inaccuracy in the operationalization of qualitative characteristics because this study combined reliable dimensions based on the Government of the Republic of Indonesia [1] with faithful representation dimensions according to Beest, Braam and Boelens [2]. Second this research measures the quality of LGFS limited to reporting entities only, has not involved the opinions of accounting entities. Third, this research has not examined the extent of the role of internal control officers in guaranteeing the quality of information quality of LGFS. Fourth, this research was conducted in 2018 to measure the quality of the LGFS in 20132016, so that it was feared that there would be a mistake in filling out questionnaires by respondents. Fifth, confirmation conducted does not involve external parties, it is feared that the information is not objective. Based on the limitations, there are several suggestions of this research. First, conduct interviews with the financial report compiler for each indicator after the results of the questionnaire are obtained. Second, to measure the quality of information the LGFS needs to involve the work unit as an accounting entity. Third, it is necessary to review the extent of the role of the internal control apparatus in guaranteeing the quality of information on the quality of the LGFS. Fourth, to conduct research in order to evaluate the
\end{abstract}

quality of information on LGFS it is necessary to do it directly in each of the reporting years to maintain the accuracy of the data from the questionnaire and confirmation results. Fifth, make a confirmation involving external parties of the regional government to ensure the objectivity of information obtained by involving external auditors or the community.

\section{Keywords - information quality, accrual basis, fixed asset}

\section{INTRODUCTION}

The reform of the public sector in Indonesia as a demand for the needs of the community in 1998 brought major changes to the governance system in Indonesia. The centralized government system was changed to a decentralized government system based on the amendments of the 1945 Constitution of the Republic of Indonesia which were carried out at four stages in a series. The transfer of authority based on the principles of decentralization, deconcentration and co-administration from the President to the autonomous regions has the consequence of the transfer of local financial management powers [3]. The local government accepts the local financial management power from the President as the holder of state financial management [4]. Based on the obtained of local financial management power, the local government as a reporting entity can independently manage the Local Budget. Such independence is marked by the independence of the local government to compile, implement and account for the Local Budget.

Public sector reform in Indonesia in accordance with the concept of New Public Management supports changes in recognition systems and accounting measurements to provide more appropriate information for decision making [5]. In line with this, accounting reforms which according to Nogueira, Margarida and Oliver [6] can have an impact on public sector financial reporting. State financial reforms in Indonesia experienced fundamental changes through the establishment of Law Number 17 of 2003 concerning State Finance, Law Number 1 of 2004 concerning State Treasury and Law Number 15 of 2004 concerning Examination of Management and Responsibility for State Finance. The consequences of the state financial reforms, particularly in public sector accounting in Indonesia, are changes in cashbased government accounting standards to accrual-based 
government accounting standards, with an adjustment process through the application of cash towards accrualbased government accounting standards $[4,7,3]$.

According to Carrol and Marlowe [8], accrual-based accounting can improve professionalism, accountability, comparability and transparency of financial statements. Furthermore, according to Khan and Mayes (2009) in Huda [9], there are several reasons for rationalizing the application of accrual-based accounting to the public sector, namely, the first accrual basis can measure the amount of assets and liabilities in accordance with fiscal policy and fiscal sustainability. Second, the accrual basis is able to present information on the amount of full cost for activities carried out by the government. Third, the accrual basis can encourage the development of systems and procedures related to planning and management of assets and liabilities. Fourth, the accrual basis encourages changes in managerial behavior and the level of budget decision makers.

The application of accrual-based government accounting standards is based on the mandate of the Government of the Republic of Indonesia [4] which is translated in the Government of the Republic of Indonesia [3], which mandates the implementation of accrual-based government accounting standard at the latest of 2015 for both the central government and local governments. With this arrangement, the application of the latest cash towards accrual-based government accounting standards was used in the 2014 reporting year.

The accounting base changes applied by the Government of the Republic of Indonesia for both the central government and local governments, in addition to carrying out the mandate of regulation are also intended to present relevant information on the government's financial position and all transactions carried out by reporting entities during the reporting period, knowing the value of economic resources used to carry out its operational activities, assess the financial condition of the government, evaluate the effectiveness and efficiency of the performance of reporting entities, and help assess compliance with laws and regulations [3]. The information produced is expected to help or influence the decision making of public officials efficiently, effectively and economically. This is in accordance with the opinion of Blondal [10], that accrualbased accounting is able to increase the quantity and quality of financial reports in the context of decision making both for internal managerial and public accountability.

In order to account for the implementation of the Local Budget, as a reporting entity the local government is obliged to prepare and present financial statements [11]. Local Government Financial Reports (LGFS) are prepared based on government accounting standards [4]. According to IPSASB [12], the purpose of public sector financial statements is to provide information about these entities that are useful for the general purpose of financial statements in the context of accountability and decision making.

Referring to IPSASB [12], a complete category of financial statements for the public sector consists of financial position reports, financial performance reports, changes in net assets/equity reports, cash flow reports, budget realization reports for entities that publish budgets and notes to financial statements. According to the
Government of the Republic of Indonesia [7], when implement cash towards accrual-based government accounting standards, it is obligatory to present financial reports consisting of Budget Realization Reports, Balance Sheet, Cash Flow Statements and Notes to Financial Statements. Furthermore, according to the Government of the Republic of Indonesia [3], when implement accrualbased government accounting standards the government is required to present financial reports consisting of Budget Realization Report, Operational Report, Balance Sheet, Statement of Changes in Equity, Report on Changes in More Budget Balance, Cash Flow Report and Notes to Financial State-ments. Thus, it is seen that the representation of accrual-based government accounting standards has been adjusted to international standards of public sector accounting.

In contrast to the explanation above related to the application of accrual basis to the public sector in Indonesia both from the mandate of legislation and from the side of benefits, the application of accrual basis to the public sector at the international level has become a debate among writers both in terms of theory and practice and also for consequences its application (Montesinos et al., 1995; Guthrie, 1998; Brorstrom, 1998; Christiaens and Rommel, 2008; Lapsley, 2009; [5, 6]). Furthermore, it is explained that this is due to the nature of the public sector which is primarily not for the purpose of seeking profit and diversity of activities in the public sector which contributes to the application of accrual-based accounting into question [6].

However, at the international level, those who support the application of the accrual basis in the public sector emphasize accrual basis benefits such as the availability of information that is useful for decision making, provide additional information that is useful for transparency, and provide information on responsibilities and measures of public sector performance for the benefit of users report (Pallot, 1997; Brorstrom, 1998; Guthrie, 1998; Brusca and Condor, 2002; IFAC-PSC, 2002; Chan, 2003; Pina and Torres, 2003; Van der Hook, 2005; Anessi-Pessina and Steccolini, 2007; FEE, 2007; Montesinos and Brusca, 2009; Pina et al., 2009; [5, 6]). Besides that, with the development of public sector management that prioritizes performance and accountability, the cash base is seen as unable to compensate for changes in the information needs of the public sector so that the cash base is considered inaccurate in describing the economic and financial situation of the organization and unable to provide sufficient and useful information in the control process, planning and performance measurement $[13,14]$.

With the existence of parties who are pro and contra on the application of the accrual basis, the Indonesian government still chooses to implement the accrual basis to both the central government and local governments with various considerations as outlined above and regulated through legislation. However, if viewed from the side of measuring the quality of financial statement information on the accrual basis in the public sector, especially in the Indonesian government, there is no measure of the quality of LGFS information can provide evidence that the accrual basis is more useful than the base used (cash toward accrual). 
Until now, the only benchmark that can be used to assess the LGFS produced based on government accounting standards in force in Indonesia is through the provision of opinion by The Audit Board of The Republic of Indonesia on the LGFS's fairness assessment. Based on the Government of the Republic of Indonesia [15], the basis for The Audit Board of The Republic of Indonesia opinion review was based on four criteria, namely, conformity with government account-ting standards, adequacy of disclosures, compliance with laws and regulations, and effectiveness of internal control systems. The Audit Board of The Republic of Indonesia opinion includes, Unqualified Opinion, Qualified Opinion, Adverse Opinion and Disclaimer Opinion [15].

Based on the data in Fig 1, The Provincial Government of East Nusa Tenggara at the time of implement the cash toward accrual basis (2013 - 2014) obtained Qualified opinion, while at the time of implement the accrual basis there was an increase in the acquisition of opinions into Unqualified Opinion (2015 - 2016). Specifically, the description of the opinion acquisition of The Provincial Government of East Nusa Tenggara for the 2013-2016

Budget Year is presented in Fig 1.

Fig. 1. Data on the Growth of Auditor Board Opinion by The Provincial Government of East Nusa Tenggara for year 2013 to 2016

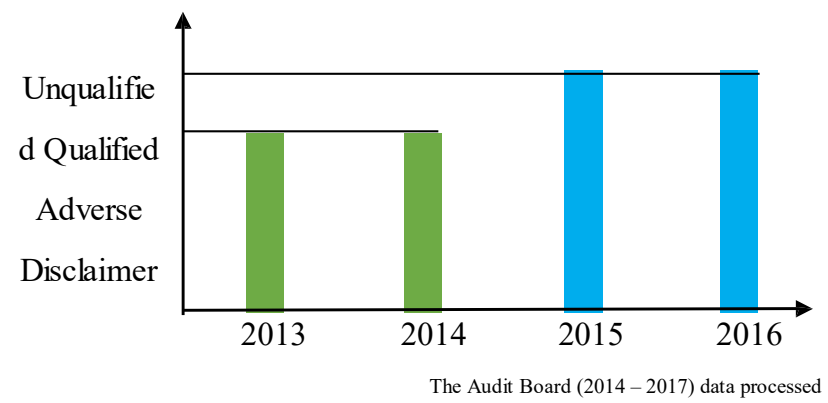

Fig. 2. General Description of the Composition of Fixed Assets to Total Assets in the Balance Sheet of The Provincial Government of East Nusa Tenggara for 2013-2016

\section{Rp6,000,000,000,000.00 \\ Rp5,000,000,000,000.00 \\ Rp4,000,000,000,000.00 \\ Rp3,000,000,000,000.00 \\ $\mathrm{Rp} 2,000,000,000,000.00$ \\ $\mathrm{Rp} 1,000,000,000,000.00$ \\ Rp0.00 \\ Current Asset \\ Fixed Asset

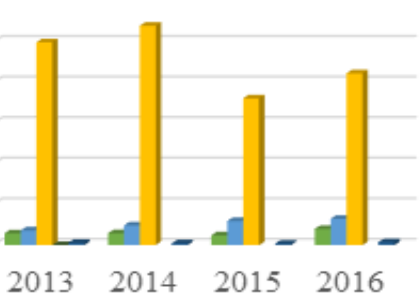 \\ Long Term Investment \\ - Other Asset \\ The Provincial Government of East Nusa Tenggara}

The basis of location selection for conducting research on the quality of information on LGFS is based on the comparison of the quality of information on LGFS when implement the cash toward accrual basis and accrual basis. It is expected that secondary data from obtaining opinion from The Audit Board of The Republic of Indonesia on the fairness of financial statements can represent a picture of the quality of LGFS information. So that valid evidence can be 
obtained whether the benefits of applying the accrual basis at the level of information quality of LGFS are better than the base previously used. For this reason, location selection is conducted based on the acquisition of The Audit Board of The Republic of Indonesia opinion which showed an increase in opinion achievement, namely the acquisition of opinions other than the Unqualified Opinion in the application of the cash toward accrual basis into the Unqualified Opinion in the year of the accrual basis, with the sample of The Provincial Government of East Nusa Tenggara.

Based on the general description of The Audit Board of The Republic of Indonesia opinion obtained by The Provincial Government of East Nusa Tenggara in 20132016 , indicates the involvement of efforts taken to ensure an increase in opinion achievements. Referring to several previous studies related to the factors that influence the quality of financial statement information [16-18], there are three factors that are relevant to the efforts made by The Provincial Government of East Nusa Tenggara. The three efforts are intended to be an increase in commitment to accounting policies, human resource development (HR) and improvement of information systems. These efforts are considered relevant to the improvement of the quality of LGFS information, because it was pursued by The Provincial Government of East Nusa Tenggara in order to obtain Unqualified Opinions in the transition period of applying the accrual basis.

Concrete problems in the use of financial statement information currently occurring in the public sector in

the LGFS is aimed only at the benefits of accountability. This was evidenced by a statement submitted to The Provincial Government of East Nusa Tenggara through an interview forum conducted on May 21, 2018 to the officials of Accounting and Reporting Sector and Local Asset Management Sector of The Board of Regional Revenue, Financial and Asset Management of The Provincial Government of East Nusa Tenggara. The substance of the interview discussed capital expenditure budgeting decisionmaking through the preparation of design documents plan for regional fixed asset needs that had not been based on LGFS information. Even though there have been repeated findings on fixed assets for the last four years from 2013 2016 [19-22].

Thus, it can be concluded that the information of the LGFS of The Provincial Government of East Nusa Tenggara has not been used optimally for decision making and is still limited to meeting the demands of accountability. On the other hand, according to IPSASB [12] a financial report is considered to have high benefits if it is able to influence decision making.

In the public sector, the value of fixed assets generally contributes materially to financial statements. Likewise, with the value of fixed assets of The Provincial Government of East Nusa Tenggara, it contributes materially to the total value of assets from year to year as shown in Fig 2. From these data, it can be seen that there was a decrease in the value of fixed assets in the transition period of the accrual basis, namely from 2014 to 2015 with the total value of fixed assets decreasing is Rp1.789.833.032.815,06 [43-44]. 
This happened because the Provincial Government of East Nusa Tenggara began to implement a depreciation accounting policy for fixed assets.

Based on the audit report of The Audit Board of The Republic of Indonesia during 2013-2016 there were successive recurring findings on the management of fixed assets. In 2013, The Audit Board of The Republic of Indonesia found that the management of fixed assets of The Provincial Government of East Nusa Tenggara in 2013 was inadequate [19]. In 2014, The Audit Board of The Republic of Indonesia found that the management of fixed assets was inadequate [20]. In 2015, The Audit Board of The Republic of Indonesia found that the management and administration of fixed assets was not fully adequate [21]. In 2016, The Audit Board of The Republic of Indonesia found that the control and administration of fixed assets in land and building was not fully adequate [22].

Based on the consideration of the material value of fixed assets to financial statements, especially the balance sheet and the repeated findings of external auditors on the management of fixed assets, the utilization of LGFS information is considered to be significant benefit to capital expenditure and fixed asset decision making. If viewed based on the relationship between capital expenditure and fixed assets, it can be stated that the output of capital expenditure budgeted for the Local Budget and reported realization in the Budget Realization Report correlates with the addition of fixed assets to the Balance Sheet. Therefore, in order to manage fixed assets as part of the local financial management cycle, it is necessary to obtain input material based on financial statements as input for budgeting for capital expenditure in the Local Budget. Specifically entering financial statement information such as depreciation value, book price of fixed assets and the condition of carrying out fixed assets can affect the decision related to capital expenditure and fixed assets during the process of preparing plan for regional fixed asset needs documents.

This research is important to do, because all this time the benefits of local government financial reports have not been used as material for decision making, only limited to the accountability documents as material for The Audit Board of The Republic of Indonesia examination. So as to provide evidence that the LGFS is appropriate to be used as material for decision making, it is necessary to evaluate the quality of information on the LGFS. After mapping the quality of LGFS information, it can be decided the feasibility of the LGFS as material for decision making. Based on the results of mapping the quality of information, efforts can be made to improve the quality of information on LGFS continuously. Furthermore, it is hoped that the LGFS information can be one of the solutions to decision-making on the management of fixed assets in the context of efforts to deal with repeated findings of fixed assets.

Previous research that was relevant to this study was carried out by several researchers. Beest, Braam and Boelens [2], regarding Quality of Financial Reporting: Measuring Qualitative Characteristics, discusses that there are constraints in measuring the quality of financial statement information because there is no operationalization of qualitative characteristics. Overcoming these problems,
Beest, Braam and Boelens [2] make operational the qualitative characteristics to measure the quality of financial statement information, by obtaining the results that the measuring instrument used is valid and reliable to measure the quality of financial information.

Hastowo [17], concerning Quality Analysis of Information on State General Treasurer Financial Statements, found that the quality of State General Treasurer financial statement information is at a basic moderate level, which means that the quality of financial statement information is inadequate in the decision-making process. To conduct this research Hastowo [17] considers that the operationalization of qualitative characteristics by Beest, Braam and Boelens [2], is closest to the qualitative characteristics of government accounting standards that apply in Indonesia [17]. The operationalization of these qualitative characteristics is adjusted to government accounting standards that apply in Indonesia (Government of the Republic of Indonesia, 2010).

Jonas and Blanchet [23], regarding Assessing Quality of Financial Reporting, obtain findings that the quality of the company's financial statements ultimately depends on each process of preparing financial statements. Pamungkas [16], concerning Determinants of the Application of the Full Accrual Basis to the Regional Government, obtained findings that HR management in financial and asset management and information technology had a positive influence on the quality of the 2015 financial year LGFS. Meanwhile, commitment to regulations and policies and information technology management did not have a significant effect on improving the quality of LGFS. Thus, this study concludes that the commitment variable on regulation and policy and IT management on the implementation of accrual-based government accounting standards in local governments does not have a positive effect on the quality of the LGFS. Conversely, the HR variable on financial, asset and information technology managers over the implementation of accrual-based government accounting standards in local governments has a positive influence on the quality of the LGFS.

Purwohartono [18] concerning Factors Affecting the Quality of Financial Statements of State Ministries/Institutions and Their Impacts on the Benefits of Financial Reporting obtained findings that HR Capacity, Organizational Commitment, Internal Control System, Information Technology Utilization had a significant positive effect on the quality of the ministry/agency financial statements, while data reconciliation on the quality of ministry/agency financial reports did not prove to have a significant effect.

Ariyani [24], regarding Optimization Analysis of the Use of Information in Financial Statements in Decision Making for Planning and Budgeting for Capital Expenditures and Maintenance Expenditures (Case Study at the Ministry of Finance), obtain findings that some financial statement information has been used in decision making in accordance with laws and regulations. However, the use of such information is not optimal because the provision of information in financial statements has not fully met managerial needs. Thus, this study concludes that the use of financial statement information in the planning and budgeting process for capital expenditure and maintenance 
has been carried out but has not been optimal because it has not considered information regarding fixed assets, capital expenditure and maintenance, depreciation and other assets, thus requiring the preparation of procedures its use.

Nogueira, et al [6], concerning The Usefulness of Financial Reporting for Internal Decision Making in Portuguese Municipalities, obtain findings that city government financial reporting shows high benefits in the context of decision making. This benefit will increase if information is presented which is more than the information required to be presented. There are two groups of decision makers who behave differently on the benefits of financial reporting, namely politicians and technical officials. Technical officials consider greater value of benefits. Furthermore, there is no statistical evidence on the relationship of training and the professional experience of internal policy makers

Referring to previous studies, related to the quality of financial statement information, the factors that affect the quality of financial statements, the benefits/usefulness of financial statements, the utilization of financial statement information in the context of capital expenditure and fixed asset decision making, have not explored quality evaluation information on financial statements of local governments in Indonesia by assessing their comparisons both before implement the accrual basis and after implement the accrual basis by taking into account the use of the financial statement information for capital expenditure and fixed asset decision making.

Based on the description above, it is interesting to do an analysis of the quality of LGFS information before and after implement the accrual basis, is it in line with the increase in the opinion of The Audit Board of The Republic of Indonesia? Furthermore, based on information on the increase in The Audit Board of The Republic of Indonesia opinion acquisition, raises questions related to what efforts have been made by The Provincial Government of East Nusa Tenggara in order to improve the quality of LGFS information related to increased accounting policy commitments, HR development and information system improvement? Finally, an interesting question that arises is how the design of the utilization of information from LGFS can be used as a material for consideration of specific decision making on capital expenditure and fixed asset policies.

To conduct this research, the period of the year under study is 2013-2016, with an analysis unit in The Provincial Government of East Nusa Tenggara. Therefore, this study is expected to contribute in the form of evaluating the quality of LGFS information before and after implement the accrual basis, efforts to improve the quality of LGFS information by regional governments and recommendations on the design of utilization of financial statement information in order to make policy decisions on capital expenditure and fixed assets.

Based on the background above, there are three formulations of the problem to be discussed. First, how is the quality of LGFS information on The Provincial Government of East Nusa Tenggara before (2013-2014) when implement cash toward accrual basis and after (20152016) when implement the accrual basis? Second, how are the efforts of the local government in improving the quality of the LGFS related to the increased commitment of accounting policies, HR development and improvement of information systems in the transition period to implement the accrual basis? Third, how is the design of LGFS utilization as material for making policy decisions on capital expenditure and fixed assets?

In accordance with the formulation of the problem, this study aims to first analyze the quality of information on the LGFS of The Provincial Government of East Nusa Tenggara before and after the application of the accrual basis. Second, analyzing the efforts of The Provincial Government of East Nusa Tenggara in improving the quality of the LGFS related to the increased commitment of accounting policies, HR development and improvement of information systems. Third, analyzing the use of LGFS as material for making policy decisions on capital expenditure and fixed assets.

The results of the research conducted are expected to provide benefits. First, the results of this study can be used to evaluate the quality of information LGFS from cash toward accrual basis into accrual basis. Thus, it can provide valid evidence to The Provincial Government of East Nusa Tenggara regarding the quality of LGFS information during 2013-2016. Second, the results of this study can map out the efforts that can be made to improve the quality of information on LGFS. Third, this research is expected to be able to provide recommendations on the utilization of LGFS in order to make capital expenditure and fixed asset decisions.

To conduct this research, qualitative research methods are used with explanatory-descriptive case study approaches. This study uses primary data and secondary data. The primary data used is the results of filling out questionnaires, interviews, and confirmations with LGFS compilers and those in charge of managing fixed assets. Secondary data used were the 2013-2016 LGFS and The Audit Board of Republic of Indonesia audit report for year 2013 - 2016 LGFS. To evaluate the quality of LGFS information, it is used to operationalize the qualitative characteristics of financial statements by Beest, Braam, \& Boelens [2] which have been adjusted to government accounting standards in Indonesia by Hastowo [17].

\section{LITERATURE REVIEW}

\section{A. Agency Theory}

The agency theory is discussed by Alchian and Demsetz [25] in his discussion of production, cost information and economic organization that is influenced by the relationship between the company and its employees associated with customers who consume products from the company. Discussion of this agency theory is part of the discussion of corporate theory rooted in economic theory. The agency theory was later developed by Jensen and Meckling [26] aimed at responding to the lack of corporate theory and complementary corporate theory and agency theory. The agency relationship is a contract between one or more persons as a principal who employs others as an agent to perform services or work on behalf of the principal and involves the delegation of some principal decision-making authority to the agent [26]. It can be interpreted that agency theory explains the relationship between principals (eg. shareholders) with agents (eg. executives and corporate 
managers). Thus, the principal employs an agent to carry out his work. According to Clark [27] shareholders delegate authority to run business to directors or managers.

In line with agency theory in the private sector where private sector organizations are accountable to shareholders or creditors, public sector organizations are accountable to society [28]. This can be interpreted that in the public sector the community acts as a principal and the government acts as an agent. Furthermore, Mardiasmo [28] explains that public sector responsibility to the community is motivated by public sector funding sources derived from the community and its performance aimed to providing services to the community. Thus, the application of agency theory to the public sector discusses public relationships that employ governments to provide public services as a government obligation.

In the framework of the implementation of public service obligations, the source of funds used by the government comes from public funds regulated in the Law on the State Budget and the Local Budget [4]. The use of State Budget/Local Budget shall be accounted in the form of financial statements [29]. Public sector liabilities of responsibilities are vertical and horizontal [28], which means the government is obliged to account for managed funds to higher authorities (vertical accountability) and accountable for the use of public funds to the public (horizontal accountability). These two accountability processes then form public accountability as an important element in the state financial accountability process.

Based on agency theory, the Provincial Government of East Nusa Tenggara places the task and function of providing public services to the community as principals. The contractual form between The Provincial Government of East Nusa Tenggara and the people it serves then receives oversight from The East Nusa Tenggara House of Representatives to represent the community in overseeing the implementation of the functions of the local government.

The Provincial Government of East Nusa Tenggara must annually account for the implementation of the Local Budget through a joint discussion of the Draft of Local Regulation on the Accountability of Local Budget Implementation with the East Nusa Tenggara House of Representatives. Submission of the Local Regulation Draft concerning Accountability for Local Budget Implementation was submitted to The East Nusa Tenggara House of Representatives no later than 6 (six) months after the fiscal year ended, after being audited by The Audit Board of The Republic of Indonesia [4]. Thus, the LGFS submitted to The East Nusa Tenggara House of Representatives is an audited LGFS and receives an opinion from The Audit Board of The Republic of Indonesia.

The Provincial Government of East Nusa Tenggara as an agent must account for the management of the Local Budget which is its responsibility to the community. In order to increase accountability to the community and improve the quality of information on LGFS, The Provincial Government of East Nusa Tenggara pursued efforts to improve the quality of the LGFS through increased commitment to accounting policies, HR development and improvement of information systems. Furthermore, in order to carry out services to the community The Provincial
Government of East Nusa Tenggara requires the support of facilities and infrastructure which are recorded as fixed assets on the government balance sheet. For this reason, it is important for The Provincial Government of East Nusa Tenggara to manage its fixed assets adequately.

\section{B. Good Governance}

According to UNDP (1997) in IFAD [30], accountability is one of the pillars of good governance that requires decision makers in government, private sector and community organizations to be accountable to the public as well as their respective institutional stakeholders. Furthermore, according to ADB (1999) in IFAD [30], accountability relates to the obligations of individuals and organizations with a public mandate to be responsible for actions taken to the public as the source of their authority. One of the dimensions of accountability is financial accountability [28]. Agents are responsible to the principal for managing the funds used in providing public services. Accountability allows principals to evaluate and provide an assessment of the agency's accountability for the execution of activities in fund management. Based on the Government of Indonesia [29], the form of government accountability is financial state-ments.

Furthermore, according to UNDP (1997) in IFAD [30] transparency is one of the pillars of good governance built on the concept of free information, so that processes, institutions and information must be directly accessible to the parties concerned, and sufficient information must be provided to make users easy to understand and do monitoring. Further, according to World Bank (1994) in IFAD [30], information transparency is part of good governance and strengthens accountability. Private sector investment decisions are judged rely on public knowledge of government policies and information provided by governments about economic and market conditions (IDA, 1998 in [30]). The transparency of decision-making, particularly in budget processes, regulation and procurement is also seen as a factor that plays an important role in the effectiveness of resource use and reduction of corruption and waste (IDA, 1998 in [30]).

Based on the Government of Indonesia [31], the government should submit information on the accountability of the State Budget/Local Budget to the public through the representation of House of Representatives/Local House of Representatives, after being examined by the State Audit Board. Based on this information then conducted a joint discussion between the executive and legislative to set as a law/local regulation on the accountability of the implementtation of the State Budget/Local Budget.

\section{Financial Statements}

"The financial statements are one of the diverse information that users use for decision making" [32]. In line with the statement, according to FASB [33] financial statements are not only the end result but are intended to provide useful information in making business and economic decisions. From several definitions of these financial statements describing the value of the urgency of financial statements in addition to public sector accountability and transparency of financial information, it also plays a role in decision making from users of financial statements. 
Based on the Government of the Republic of Indonesia [11], "financial statements are a form of accountability for state/local financial management during a period" (p.2). The government's financial report is expressed as a form of statement of government accountability to the public. In line with this, the financial statements are intended for the general purpose of meeting the needs of users consisting of communities, legislative bodies, inspectors or supervisors, donors, investments and loans and government [3].

\section{The Development of Financial Reporting in Indonesia}

The development of public sector reporting in Indonesia has recorded three types of accounting bases in accordance with the classification of Nordiawan and Hertianti [34]. Prior to the enactment of Government Regulation Number 24 of 2005 Concerning Government Accounting Standards, the Indonesian government used the cash basis as the basis for accounting. Since the state financial reforms have been established through the tripartite state finance laws, mandating the change of the accounting base on government becomes the basis of accruals. Following up on the mandate, the government made changes to the accounting base through a process of adjustment by determining the use of the cash toward accrual basis [3]. Furthermore, through the enactment of Government Regulation Number 71 of 2010 Concerning Government Accounting Standards, the implementation of accrual basis is mandated for the most recently implemented starting in 2015 .

The cash basis is an accounting basis that recognizes transactions and events at the time of receipt or payment of cash or cash equivalents [35]. In accordance with the statement, Nordiawan and Hertianti [34], stated that the cash basis recognizes transactions when cash is received or paid and has a focus on cash-based measurement.

The cash toward accrual basis is the transition from the cash basis to the accrual basis by recording revenues, expenditures and financing on a cash basis while assets, debt and equity are recorded on an accrual basis [7]. Based on the cash toward accrual basis the government is mandated to present the four components of financial statements namely Budget Realization Report, Balance Sheet, Cash Flow Statement and Notes of The Financial Statements. The implementation of the last accounting standards of cash toward accrual basis is applied in 2014 by the central government as well as local government.

According to IPSASB [36] the accrual basis is an accounting basis that recognizes transactions and other events when they occur (not only when cash and cash equivalents are received or paid), for which transactions and events are recorded and presented in the financial statements in the periods of transactions and events. Further described elements known in accrual accounting for the public sector are assets, liabilities, net assets/equity, income and expenses [36]. Based on the Government of Indonesia [3], "Government Accounting Standard Based on Accruals is a standard that recognizes revenue, expenses, assets, debt and equity in accrual basis financial reporting, and recognizes revenues, expenditures and financing in the reporting of budget execution based on the basis set forth in State Budget/ Local Budget". In order to achieve the objectives of the financial statements, the components of the financial statements that must be available are in accordance with government accounting standards, namely the Budget Realization Report, Balance Sheet, Operational Report, Cash Flow Report, Changes in Equity Report, Report on Changes in Budget Balance and Notes to Financial Statements [7].

\section{E. Operationalization of Qualitative Characteristics of Financial Statement}

The operationalization of qualitative characteristics used by Beest, Braam and Boelens [2], is intended to create a comprehensive measuring tool for measuring the quality of financial statements based on qualitative characteristics in accordance with FASB and IASB arrangements in the Conceptual Framework for General Purpose Financial Statements [2]. To make this operationalization Beest, Braam and Boelens [2], using five qualitative characteristics of relevance, honest presentation, comprehensibility, compara-bility and timeliness. To measure the five qualitative charac-teristics, Beest, Braam and Boelens [2] made 21 items questions index.

In order to be used to measure the quality of government financial reporting information in Indonesia, the operationalization of qualitative characteristics of Beest, Braam and Boelens [2] needs to be adjusted to the qualitative characteristics of financial statements in accordance with government accounting standards [3]. Such adjustments have been made by Hastowo [17] to measure the quality of the General Treasurer's information with the several adjustments. First, 5 (five) dimensions of information quality are adjusted into 4 (four) dimensions of information quality. Each dimension according to Beest, Braam and Boelens [2] is adapted to the definitions, characteristics and elements of government accounting standards [3]. Second, rearrange 21 (twenty one) question items into 22 (twenty two) question items in accordance with government accounting standards [3]. Third, scores for each item of questions based on Likert scale size by considering the measurement of qualitative characteristics of Beest, Braam and Boelens [2] with conformity to government accounting standards [3]. The scale range 1-5 has a different meaning reduction starting from "scale 1" which means that the financial statement information presented does not contain information about the dimensions of quality information, up to scale " 5 " which means the information on the financial statements have met the criteria of the dimension quality information.

In order to measure the quality of LGFS information on local governments, the operational adjustment of qualitative characteristics by Hastowo [17] was re-adjusted based on the context of accounting and reporting of regional government based on legislation in the area of local financial management. For this reason, 22 (twenty two) indexes of questions by Hastowo [17] were adjusted to 23 (twenty three) indexes of questions in accordance with accounting and reporting of local government.

\section{RESEARCH METHOD}

The research method used is qualitative research method with explanatory-descriptive case study approach. This research was conducted with a qualitative approach because it was appropriate to answer the formulation of the problem that needed a descriptive explanation. Furthermore, the selection of the use of the case study method is appropriate 
for this research because it can answer the formulation of the problem that requires in-depth analysis.

This research uses primary data and secondary data. Primary data used is the result of filling questionnaires, interviews, and confirmation to the compilers of LGFS and parties in charge of managing fixed assets. Secondary data used is local government financial statements year 20132016 and Report on The Result of Examination of The Audit Board over LGFS for year 2013-2016.

Data collection techniques in this research are questionnaires, interviews and confirmation to obtain primary data and documentation and content analysis to obtain secondary data. Questionnaires were submitted to the compilers of LGFS, namely the Accounting and Reporting Sectors of the Board of Local Revenue, Financial and Asset Management. Interviews and confirmations were made to officials and employees in the Accounting and Reporting Sector and in the Local Asset Management Sector.

The research instrument used is questionnaire and list of interview question. The questionnaire contains a number of questions relating to the measurement of the operationalization of qualitative characteristics to measure the quality of LGFS. The next list of interview questions is used to analyze the efforts that local governments have made in improving the quality of LGFS information and analyzing the utilization design of LGFS information in the framework of decision making of capital expenditure budget and fixed asset.

In order to obtain primary data, questionnaires are compiled based on the adjustment of operationalization of qualitative characteristics of financial statements by Beest, Braam and Boelens [2] that have been adapted to the context of government accounting standards in Indonesia and the characteristic of accountability of Local Budget implementtation by local government. Adjustment of operationalization of qualitative characteristics of financial statements in accordance with the context of government accounting standards in Indonesia was previously undertaken by Hastowo [17]. To be applied to the local government context, adjustments are made in accordance with the context of financial reporting to local governments. Interviews were conducted with a structured question form given to the respondent and progressed during the interview process. Respondents who become the object of research and fill in questionnaires and interviews in this study consist of officials and staffs at the Board of Local Revenue, Financial and Asset Management of The Provincial Government of East Nusa Tenggara.

The last stage of primary data collection after the questionnaires and interviews are done is confirmation. Confirmation was made to the contents of the questionnaire and the interview answers to the compilers of LGFS and the Local Asset Management Sector. Confirmation of the interview to the Local Asset Management Sector shall be made to the Field of Accounting and Reporting.

Secondary data is obtained first rather than primary data, so the substance of the preparation of questionnaires and interview questionnaires has been attempted to consider the condition of the unit of analysis. The unit of analysis in this study is set to be conducted at the Provincial Government of
East Nusa Tenggara. The selection of the analytical unit is based on the consideration of obtaining a qualified opinion when implement the cash toward accrual basis (2013-2014) and increasing by obtaining unqualified opinion upon implement the accrual basis (2015-2016).

To analyze the data, this study uses data reduction techniques, data presentation and conclusion/verification [37]. To measure the quality of financial statement information, this study uses the qualitative characteristics of operationalization qualities [2], which are adjusted according to government accounting standards applicable in Indonesia. Based on these criteria will be given a score with a value of 1 to 5 . Then, the result score is confirmed to the authors of LGFS. The results of this study are expected to evaluate the quality of LGFS information before and after implement accrual-based accounting along with the factors that influence.

In order to measure the quality of LGFS information, the adjustment of the operationalization of qualitative characteristics by Hastowo [17] is re-adjusted based on the accounting and reporting context of local government based on legislation in the field of local financial management. Therefore, 22 (twenty two) question indexes by Hastowo [17] are adjusted to 23 (twenty three) index questions in accordance with the accounting and reporting of local government.

In order to draw conclusions related to efforts undertaken to improve the quality of local government financial statements conducted based on the results of interviews and confirmation to the compiler of local government financial statements and review of Report on The Result of Examination of The Audit Board content. Furthermore, to draw conclusions regarding the design of the utilization of local government financial statements information in capital expenditure budgeting is made based on the results of interviews and confirmations to the compilers of local government financial statements namely the Accounting and Reporting Sector and Asset Management Sector. In addition, an analysis of LGFS content that has been examined by The Audit Board is conducted to see the relationship between capital expenditure budget and fixed assets, as well as documents related to the design of unit needs (used before and in 2016) and the design of the needs of local fixed asset plan (used since 2017).

\section{RESEARCH FINDINGS AND DISCUSSIONS}

\section{A. Information Quality of Local Government Financial Statement}

The quality of LGFS information during 2013-2016 as shown in table 1 obtained scores of $69.75,78.69,82.56$ and 82.94 respectively. The average quality of information each year is $3.11,3.51,3.69$ and 3.70 respectively, which means that the quality of information on LGFS is at a moderate level (3.00 - 3.99). Moderate level for the quality of financial statement information means that the quality of information on the LGFS of The Provincial Government of East Nusa Tenggara is sufficient to be used as material for decision making.

From this data it can be concluded that the quality of LGFS information on a cash basis towards accruals (in 
2013-2014) was 69.75 or $62.28 \%$ and 78.69 or $70.26 \%$ experienced an increase in the quality of LGFS information when implement accrual basis (in 2015 - 2016) amounting to 82.56 or $73.72 \%$ and 82.94 or $3.70 \%$. The increase that has occurred is not significant because it is still at the same level of quality value, namely moderate. When compared with the acquisition of opinion from The Audit Board of The Republic of Indonesia on the 2013-2016 LGFS, which experienced an increase in qualified opinion acquisition in 2013-2014 into unqualified opinion in 2015-2016, it can be stated that the quality of LGFS information is consistent with the increase in opinion of The Audit Board of The Republic of Indonesia when implement the cash toward accrual for 2013-2014 into the accrual basis for 2015-2016.

If viewed based on the acquisition of the value per dimension of the quality of financial statements in a row from the lowest value to the highest value that is, comparable, understandable, reliable and relevant. Based on these measurements, there is still room for continuous improvement of the quality of LGFS information from The Provincial Government of East Nusa Tenggara.

Comparable dimension obtains the lowest score, confirmed because the LGFS of The Provincial Government of East Nusa Tenggara is still used as limited as accountability goals to be submitted to The Audit Board of The Republic of Indonesia in the context of financial audits. Understandability dimension confirmed yet optimally fulfilled, because there are not many ratios that can help the user's understanding and not yet equipped with a glossary.

The reliable dimension confirmed to be able to increase from moderate level in 2013-2015 became a high level in 2016 because The Provincial Government of East Nusa Tenggara tried every year to improve the presentation and disclosure of the conditions for implementing the local government budget completely, honestly and equipped with traceable data sources. Relevant dimension confirmed to be able to increase from moderate level in 2013 to 2014 became high levels in 2015 to 2016 because the Provincial Govern-ment of East Nusa Tenggara improved the presentation of LGFS in a timely manner, disclosed complete events on Notes to Financial Statements and presented valid financial figures to be made prediction of future fiscal years and corrections to previous years.

1) Relevant

The relevance of information in the LGFS means the capability of the LGFS's information in making changes to

TABLE I. LOCAL GOVERNMENT FINANCIAL STATEMENTS INFORMATION QUALITY OF THE PROVINCIAL GOVERNMENT OF EAST NuSA TENGGARA FOR YEAR $2013-2016$

\begin{tabular}{|c|l|c|c|c|c|c|c|c|c|}
\hline No & \multicolumn{1}{|c|}{ Dimension } & $\mathbf{2 0 1 3}$ & Average & $\mathbf{2 0 1 4}$ & Average & $\mathbf{2 0 1 5}$ & Average & $\mathbf{2 0 1 6}$ & Average \\
\hline R & Relevant & 23,69 & 3,38 & 26,75 & 3,82 & 28,31 & 4,04 & 28,38 & 4,05 \\
\hline A & Reliable & 15,69 & 3,14 & 18,44 & 3,69 & 19,69 & 3,94 & 20,00 & 4,00 \\
\hline D & Comparable & 14,81 & 2,65 & 16,69 & 2,98 & 17,25 & 3,08 & 17,25 & 3,08 \\
\hline P & Understandability & 15,56 & 3,24 & 16,81 & 3,50 & 17,31 & 3,61 & 17,31 & 3,61 \\
\hline Information Quality & \multicolumn{2}{|c|}{$\mathbf{6 9 , 7 5}$} & $\mathbf{7 8 , 6 9}$ & $\mathbf{8 2 , 5 6}$ & $\mathbf{8 2 , 9 4}$ \\
\hline Maximum Value & \multicolumn{2}{|c|}{$\mathbf{1 1 2}$} & $\mathbf{1 1 2}$ & $\mathbf{1 1 2}$ & $\mathbf{1 1 2}$ \\
\hline \multicolumn{2}{|c|}{$\mathbf{6 2 , 2 8} \%$} & $\mathbf{7 0 , 2 6 \%}$ & $\mathbf{7 3 , 7 2 \%}$ & $\mathbf{3 4 , 0 5 \%}$ \\
\hline
\end{tabular}

TABLE II. RELEVANCE OF LOCAL GOVERNMENT FINANCIAL STATEMENTS INFORMATION

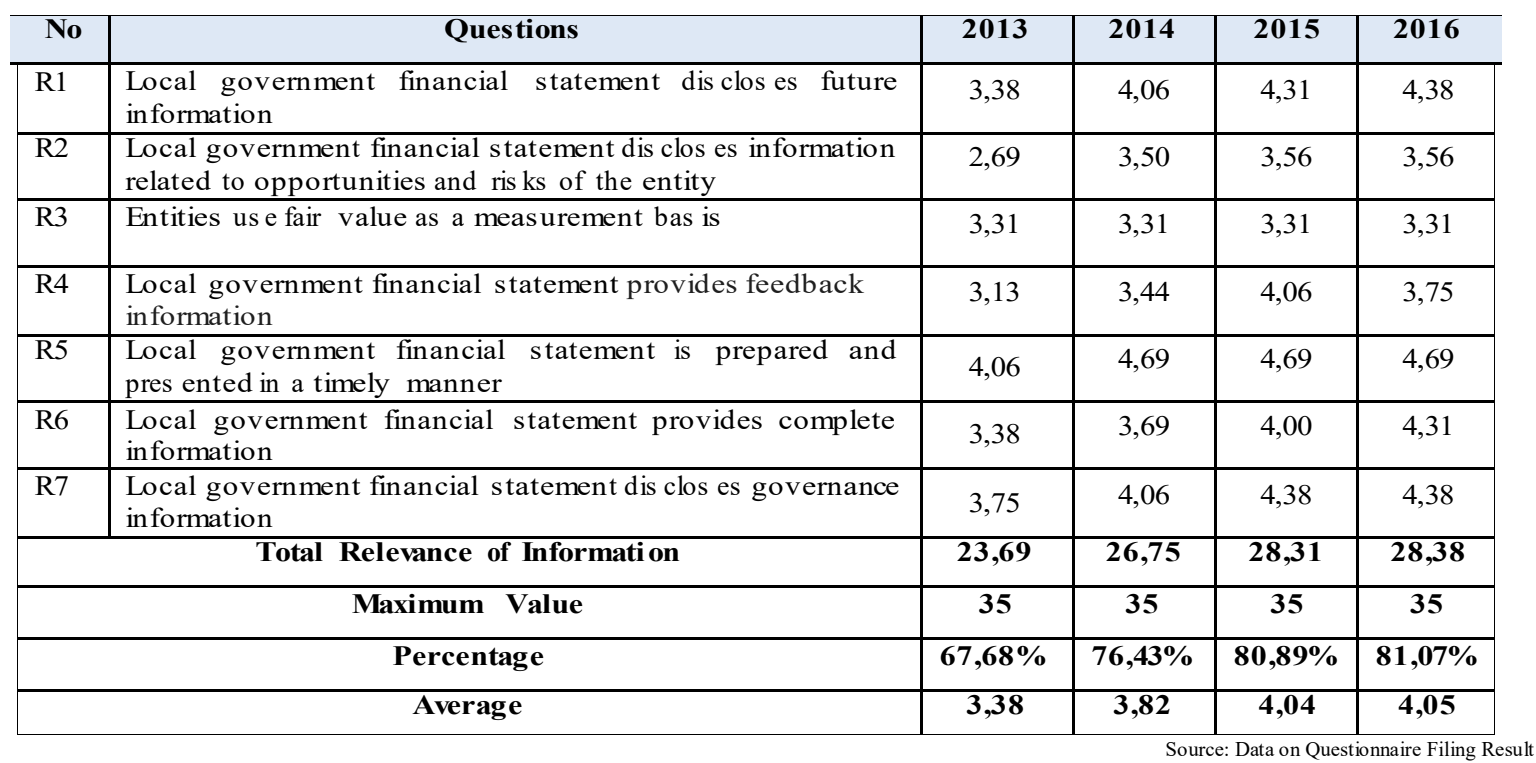


user decision making by providing information as a basis for evaluating past and present events, estimating the future and helping to provide a basis for making corrections to the results of past evaluations. Relevant consists of the concept of predictive benefits, benefits of feedback, timely, and complete.

The first question aims to measure the extent to which information in the LGFS can help users make predictions and future expectations based on past results and current events. The second question aims to measure the extent to which non-financial information presented in the LGFS is able to complement financial information in expressing opportu-nities and risks faced (R2). The third question aims to measure the extent to which local governments use fair value in addition to historical value (R3). Government accounting standards emphasize the use of historical values because they are considered more objective and can be verified.

The fourth question aims to measure the extent to which information in the LGFS allows users to confirm or correct past expectations of users (R4). The fifth question aims to measure the timeliness of the local government to prepare the LGFS (no later than March 31), submit the LGFS to The Audit Board of The Republic of Indonesia (no later than March 31) and when The Audit Board of The Republic of Indonesia as an external auditor gives an opinion that makes the LGFS an audited report so that it can be presented as information for decision making before the information loses its capacity (R5).

The sixth question aims to measure the extent to which information in the LGFS is presented as completely as possible including all accounting information that can influence decision making (R6). The seventh question aims to measure the extent to which local governments provide information on governance in the Government Governance (R7). Table 2 provides an overview of the results of measuring the relevance of information for the LGFS of The Provincial Government of East Nusa Tenggara in 2013-2016.

Based on the information in table 2 below, the relevance of information on the LGFS of The Provincial Government of East Nusa Tenggara has increased from the time the application of the cash toward accrual basis in 2013-2014 with a score of 23.69 or $67.68 \%$ and $26.43 \%$ to become accrual basis in $2015-2016$ with a score of 28.31 or $80.89 \%$ and 28.38 or $81.07 \%$. This increase can be said to be significant because it is at a different level of information quality, that is, from moderate level when implement the cash toward accrual being a high level when implement the accrual basis. This means that the LGFS when implement the accrual basis is adequate and has the capability to influence the decision making by the user.

\section{2) Reliable}

The reliability of information in LGFS means that the presentation of financial statements does not provide misleading information and does not contain material errors so that every fact is presented honestly, complete and verifiable. The first question aims to measure the extent to which information in the LGFS honestly describes each transaction and other events that should be presented or which can reasonably be expected to be presented (A1). The second question aims to measure the extent to which information in the LGFS is presented fairly based on the opinion of the external auditor on the LGFS (A2).

The third question aims to measure the extent to which the information presented in the LGFS can be tested and if the test is conducted more than once by different parties it will produce a conclusion that is not much different (A3). The fourth question aims to measure the extent to which local governments base the selection of certain accounting principles in the regulation of local heads on accounting policies to present valid information in the LGFS (A4). The fifth question aims to measure the extent to which information in the LGFS is directed at general needs and does not favor the needs of certain parties (positive events and negative events are presented in a balanced manner) (A5). Table 3 provides an overview of the results of measuring the reliability of LGFS information for The Provincial Government of East Nusa Tenggara in 2013 2016.

Based on the information in Table 3, the reliability of LGFS information from The Provincial Government of East Nusa Tenggara has increased from the implementation of cash towards accrual basis in 2013 - 2014 with a score of 15.69 or $62.75 \%$ and 18.44 or $73.75 \%$ to accrual basis in $2015-2016$ with a score of 19.69 or $78.75 \%$ and 20 or $80.00 \%$. This increase can be stated to be significant for the second year of accrual basis implementation because in 2016 there was an increase in the reliability of LGFS information from moderate level when implement the cash toward accrual basis and the first year implement the accrual basis to a high level in the second year on the accrual basis. This means that the LGFS when implement the cash toward accrual and in the first year implement the accrual basis is adequate in terms of (1) provide information that does not mislead users and is free from material errors, (2) presents every event honestly, (3) presents complete transaction or event information, and (4) provide information that can be verified.

Furthermore, based on the above measurements in the second year the application of the accrual basis, LGFS of The Provincial Government of East Nusa Tenggara already has high capability in terms of information reliability. Thus, it can be stated that the information in The Provincial Government of East Nusa Tenggara LGFS has been presented without providing information that misleads the user and does not contain material errors so that every fact in the LGFS is honestly presented, complete and verifiable. 
TABLE 33. RELIABILITY OF LOCAL GOVERNMENT FINANCIAL STATEMENT INFORMATION

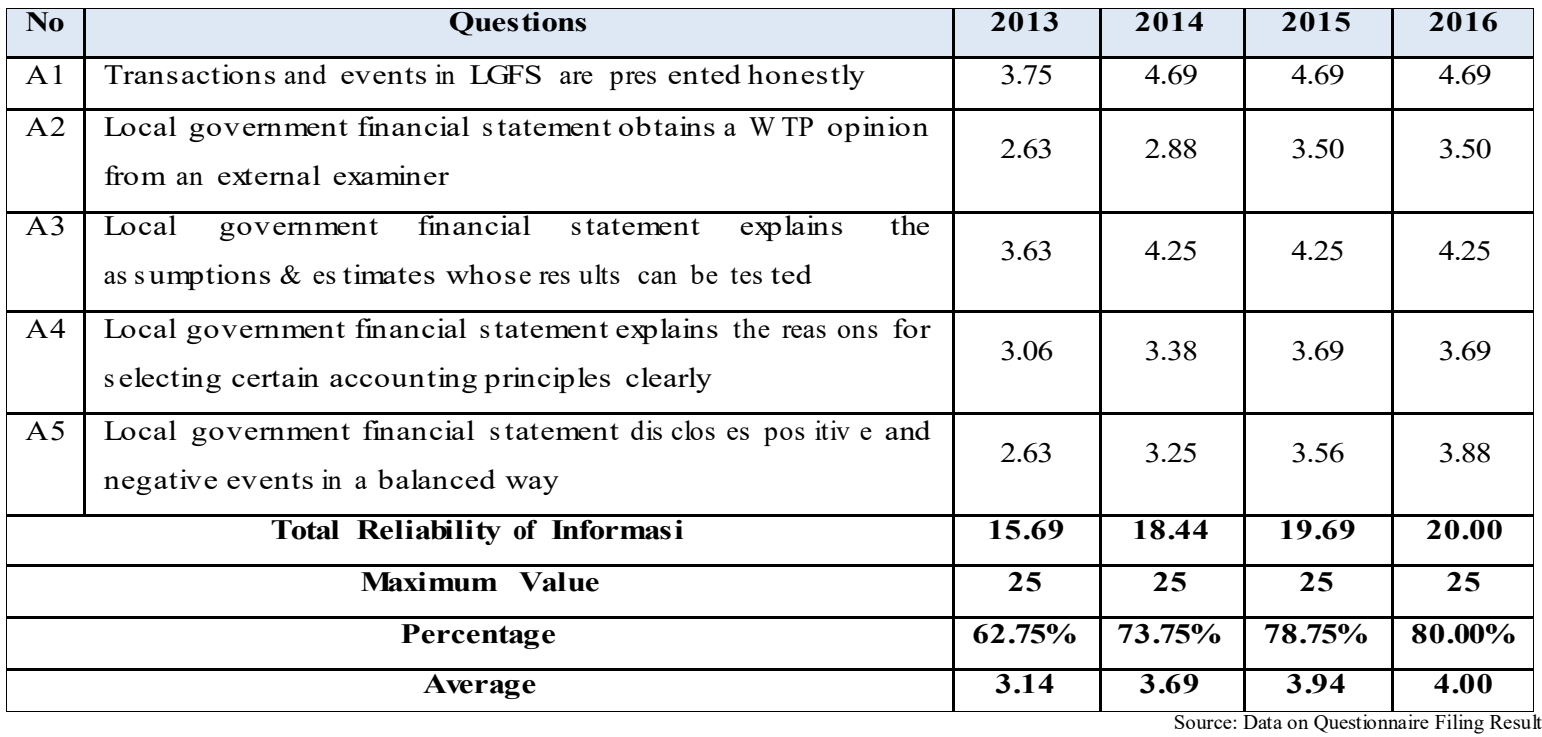

\section{3) Comparable}

Information comparability or comparability of information in LGFS means that the quality of information is able to provide an opportunity for report users to know similarities and differences both internally which means providing inter-year and external comparisons which means they can be compared with other entities. The first question aims to measure, the extent to which Notes to Financial Statements explains changes in accounting policies and the effects they cause (D1). The second question aims to measure the extent to which Notes to Financial Statements describes changes in accounting estimates and the impact of changes made (D2). The third question aims to measure, the extent to which the entity adjusts the numbers of the previous accounting period, as a result of implementing changes in accounting policies or corrections to accounting estimates (D3).

The fourth question aims to measure, the extent to which the entity provides a comparison of the results of the current accounting period with the previous period (D4). The fifth question aims to measure the extent to which information in the LGFS can be compared with other entity LGFSs in general (D5). The sixth question aims to measure, the extent to which the reporting entity presents financial analysis, such as ratios, trends, and variants in financial statements. Table 4 provides an overview of the results of the comparative measurement of LGFS information from The Provincial Government of East Nusa Tenggara in 2013-2016.
Based on the information in Table 4, the comparative information of the LGFS of The Provincial Government of East Nusa Tenggara has increased from the time the implement of the cash toward accrual basis in 2013-2014 with a score of 14.81 or $52.90 \%$ and 16.69 or $59.60 \%$ became the accrual basis in 2015-2016 with a score of 17.25 or $61.61 \%$ and 17.25 or $61.61 \%$. The acquisition of this score shows that when implement the cash toward accrual, LGFSs are at a low level and experience an increase in information appeal when implement the accrual basis to moderate level. This means that the LGFS when implement the accrual basis is adequate in terms of providing comparative information between periods (internal) and comparative information with other (external) entities.

\section{4) Understandability}

The understanding of information in the LGFS is a measure of the ease of information presented in the LGFS to be understood by the user. The size of the power of understanding information can increase if information is classified in detail and presented clearly and concisely. The first question aims to measure, the extent to which information in the LGFS is presented in an organized manner (P1). The second question aims to measure, the extent to which Notes to Financial Statements describes the accounts in the Budget Realization Report, Operational Report, Balance Sheet, Statement of Changes in Equity, Cash Flow Statement, and Report on Changes in Budget Balance quite clearly and adequately (P2). 
TABLE 44. RELIABILITY OF LOCAL GOVERNMENT FINANCIAL STATEMENT INFORMATION

\begin{tabular}{|c|c|c|c|c|c|}
\hline No & Questions & 2013 & 2014 & 2015 & 2016 \\
\hline D1 & $\begin{array}{l}\text { The notes to the financial statements describe the changes in } \\
\text { accounting policies including those impacted }\end{array}$ & 3,19 & 3,81 & 3,81 & 3,81 \\
\hline D2 & $\begin{array}{l}\text { Notes to the financial statements disclose the reasons and } \\
\text { considerations for changes in accounting estimates including } \\
\text { revised impacts }\end{array}$ & 3,44 & 3,81 & 4,38 & 4,38 \\
\hline D3 & $\begin{array}{l}\text { Local government financial statement presents comparative } \\
\text { figures as a result of adjustments to accounting policies and / } \\
\text { or accounting estimates }\end{array}$ & 2,44 & 2,75 & 2,88 & 2,88 \\
\hline D4 & $\begin{array}{l}\text { Local government financial statement presents a comparis on } \\
\text { of the results of financial figures with the previous period }\end{array}$ & 1,94 & 2,50 & 2,50 & 2,50 \\
\hline D5 & $\begin{array}{l}\text { Information in local government financial statements can be } \\
\text { compared with other entities }\end{array}$ & 2,19 & 2,19 & 2,06 & 2,06 \\
\hline D6 & $\begin{array}{l}\text { Local government financial statement presents financial } \\
\text { analys is }\end{array}$ & 1,63 & 1,63 & 1,63 & 1,63 \\
\hline & Total Comparability of Information & 14,81 & 16,69 & 17,25 & 17,25 \\
\hline & Maximum Value & 28 & 28 & 28 & 28 \\
\hline & Percentage & $52,90 \%$ & $59,60 \%$ & $61,61 \%$ & $61,61 \%$ \\
\hline & Average & 2,65 & 2,98 & 3,08 & 3,08 \\
\hline
\end{tabular}

The third question aims to measure, the extent to which the use of tables and images (graphs) clarifies the information presented in LGFS (P3). The fourth question aims to measure, the extent to which the use of language and certain terms in the LGFS can be easily understood and equipped with a glossary (P4). The fifth question aims to measure the size of the glossary on the LGFS. Table 5 provides an overview of the results of measurement of information comprehension power of The Provincial Government of East Nusa Tenggara LGFS 2013-2016.

Based on the information in table 5 above, the understanding of information about the LGFS of The
Provincial Government of East Nusa Tenggara has increased from the time the application of the cash toward accrual in 2013 - 2014 with a score of 15.56 or $64.84 \%$ and 16.81 or $70.05 \%$ became the accrual basis in $2015-2016$ with a score of 17.31 or $72.14 \%$ and 17.31 or $72.14 \%$. The acquisition of this score indicates that both when implement the cash toward accrual basis and accrual basis, the quality of information of the LGFS is at the moderate level. This means that the LGFS when implement the cash toward accrual basis and accrual basis is sufficient in terms of providing information that is classified in detail, clear and concise and has been presented in forms and terms that can be understood by the user. 
TABLE V. UNDERSTANDABILITY OF LOCAL GOVERNMENT FINANCIAL STATEMENTS INFORMATION

\begin{tabular}{|l|l|c|c|c|c|}
\hline No & Questions & $\mathbf{2 0 1 3}$ & $\mathbf{2 0 1 4}$ & $\mathbf{2 0 1 5}$ & $\mathbf{2 0 1 6}$ \\
\hline P1 & Local government financial statement is well organized & 2,06 & 2,69 & 2,69 & 2,69 \\
\hline P2 & Notes to the financial statements are presented clearly & 3,44 & 3,44 & 3,94 & 3,94 \\
\hline P3 & Tables and pictures describe the information presented & 4,31 & 4,63 & 4,63 & 4,63 \\
\hline P4 & $\begin{array}{l}\text { Local government financial statement is prepared with } \\
\text { Language \& terms that are easy to understand and comes } \\
\text { with a glossary }\end{array}$ & 3,69 & 3,69 & 3,69 & 3,69 \\
\hline P5 & $\begin{array}{l}\text { Local government financial statement presents index of } \\
\text { financial and ratio numbers }\end{array}$ & 2,06 & 2,38 & 2,38 & 2,38 \\
\hline & Total Unders tandability of Information & $\mathbf{1 5 , 5 6}$ & $\mathbf{1 6 , 8 1}$ & $\mathbf{1 7 , 3 1}$ & $\mathbf{1 7 , 3 1}$ \\
\hline Maximum Value & $\mathbf{2 4}$ & $\mathbf{2 4}$ & $\mathbf{2 4}$ & $\mathbf{2 4}$ \\
\hline
\end{tabular}

B. Analysis of Local Government Financial Statements Information Quality Improvement Efforts

\section{1) Increased Commitment to Accounting Policies}

The commitment to improve the quality of local government financial statements can be reflected in the substance of the Governor Regulation, which has accommodated the mandate of government accounting standards. Furthermore, the governing substance of the Governor Regulation is adjusted to the condition and needs of the region and continuous review of the implementation of both accounting entity and reporting entity.

The Provincial Government of East Nusa Tenggara in accordance with the mandate of the Ministry of Home Affairs [38], related to the determination of accounting policies and local government accounting system in accordance with accounting standards of government based on accruals on local government, has followed up in the form of The Provincial Government of East Nusa Tenggara [39] and The Provincial Government of East Nusa Tenggara [40]. Through the Governor Regulation, accounting and reporting of The Provincial Government of East Nusa Tenggara is adjusted to accrual basis of accounting since the 2015 reporting period.

The accounting policies of The Provincial Government of East Nusa Tenggara in general are in accordance with government accounting standards from the aspects of definition, classification, recognition, measurement and presentation. However, the said fixed asset accounting policy has not been detailed in detail about what should be disclosed in the Notes to the Financial Statements. There are several fixed asset management arrangements in the accounting policies that are appropriate to the conditions and needs of the Provincial Government of East Nusa Tenggara.

Besides in the form of adjustment of accounting policy and accounting system of local government, the form of commitment of The Provincial Government of East Nusa
Tenggara in order to handle technical issues related to reporting which become recurring findings on fixed assets is done in the signing of Integrity Pact of Head of accounting entity. The Integrity Pact aims to address the fixed asset issues in each accounting entity that are considered to significantly affect the local government financial statements of The Provincial Government of East Nusa Tenggara.

\section{2) Human Resource Development}

The Provincial Government of East Nusa Tenggara in the context of improving the quality of financial statements seeks to increase the capacity of human resources, including relevant parties in accounting entity. Furthermore, the development of human resources is also conducted for parties related to accounting and reporting on the local finance management unit and parties related to the management of local finance in the local finance management unit. In addition, through the Secretariat of the Local House of Representatives, improvements in understanding related to local financial management, especially the application of accrual-based accounting for the Local House of Representatives members of the Provincial Government of East Nusa Tenggara. The concrete form of human resource development in accounting entity, the local finance management unit and also Local House of Representatives through education, training and development efforts.

Human resource development through education is aimed at learning and fostering ways of thinking, conveying ideas, ideas and innovations from participants who follow education with long-term orientation. Education is given to individual Civil Servants in the scope of The Provincial Government of East Nusa Tenggara. Education is carried out through scholarships for formal education at the Master level.

Human resource development through training is aimed at improving, improving, and enhancing the ability of 
trainees when trained (short-term time orientation). Training is provided to individuals in accounting entity, the local finance management unit and Local House of Representatives. The training was conducted through technical guidance by The Provincial Government of East Nusa Tenggara Education and Training Board to all accounting entity related to local financial management.

Furthermore, specifically for accounting functions in the local finance management unit always included in the Socialization and Technical Guidance conducted by the Central Government (Ministry of Home Affairs) every year. The goal is to follow the socialization and technical guidance by the local finance management unit that is to always follow the development of legislation and also improve the capacity of the local finance management unit function.

Decision-makers with significant influence on the local financial management of the Local House of Representatives are also facilitated by the Local House of Representatives Secretariat to receive training by the central government through the Technical Guidance of Local Financial Management and the Implementation of AccrualBased Accounting at Local Governments implemented by the Ministry of Home Affairs Human Resources Development Board.

Human resource development through development methods is intended to prepare future job qualifications with long-term orientation. Development is given to the working groups of each accounting entity unit at The Provincial Government of East Nusa Tenggara related to budget preparation, accounting functions, and administration of local property. Development is carried out through focus group discussions (FGDs) between the local finance management unit and units handling budget, accounting and local property on accounting entity. This FGD is held every three months to discuss the problems and solutions of financial management in accounting entity.

\section{3) Improved Information System}

Efforts to improve the local financial information system, directed to the development of project management, human resources capacity in the field of technology and information, and improvement of operational systems and procedures (business processes). In the field of development of adequate project management, The Provincial Government of East Nusa Tenggara builds a commitment to good governance by the Governor and Local House of Representatives in terms of accountability of Local Budget implementation through transparency and accountability of government implement-tation. This concrete form of transparency and accountability is manifested through the establishment of local regulations on the accountability of Local Budget implementation in accordance with the laws and regulations. To ensure the reliability of the preparation of local government financial reports, The Provincial Government of East Nusa Tenggara uses the support of the Local Financial Management Information System in preparing financial reporting, which is being developed. As a consequence of the use of Local Financial Management Information System, The Provincial Government of East Nusa Tenggara using external consultants means in the case of involving external consultants with experience in public sector financial management.

Through organizational development, The Provincial Government of East Nusa Tenggara efforts are directed at the availability of sufficient and adequate human and financial capacity to ensure the success of the local financial information system. The Provincial Government of East Nusa Tenggara annually budgeted capacity building of information and technology management resources as well as capacity building and maintenance of existing information systems. Furthermore, The Provincial Government of East Nusa Tenggara continues to ensure the running of the roles and responsibilities of system administration and data on each accounting entity through monthly reconciliation with accounting division in accounting entity. In addition, training on both technical and non-technical level of application is continuously implemented in the framework of development.

The last effort of The Provincial Government of East Nusa Tenggara to improve information systems is changes in business processes and legislation simultaneously. The need for dynamic local financial management requires the adjustment of regulations and business processes both on accounting entity and the local finance management unit. To that end, The Provincial Government of East Nusa Tenggara made major changes to local regulations related to accounting policies and local government accounting system through the stipulation of Governor Regulation Number 21 Year 2014 Concerning Accounting Policies of The Provincial Govern-ment of East Nusa Tenggara and Governor Regulation Number 22 Year 2014 Concerning Local Government Accounting System East Nusa Tenggara Province. Through the adoption of these two Governor Regulations resulted in changes to the business process at Local Financial Manage-ment Information System by accommodating accrual-based arrangements.

\section{Local Government Financial Statement Information Utilization Plan on Decision Making Capital and Fixed Assets}

\section{1) Documents Used}

The quality of a financial report according to IASB [41] is stated when the financial statements are able to provide useful information for decision making for external parties such as investors, creditors, and others assumed to make the same decisions about the allocation of economic resources. Planning of the needs of local fixed asset before and until 2016 is prepared in the document of general fixed asset needs plan by referring to Government Regulation Number 6 Year 2006 Concerning Management of State/Local Fixed Asset and Regulation of the Minister of Home Affairs Number 17 Year 2007 Concerning Technical Guidance on Management of Goods Area.

The Provincial Government of East Nusa Tenggara shall adjust the document of the needs of the unit into a plan for the needs of local property based on Government Regulation Number 27 Year 2014 Concerning Guidelines for Management of State/Local Property replacing Government Regulation Number 6 Year 2006 and Regulation of the Minister of Home Affairs Number 19 Year 2016 Concerning Guidelines for Management of Local Property 
replaces the Regulation of the Minister of Home Affairs Number 17 Year 2007.

\section{2) Parties Involved}

In the framework of budgeting of capital expenditures and fixed assets of parties involved namely accounting entity which proposes and functions of budget and function of asset manager at the local finance management unit. In the current budgeting process, the parties have used the plan for the needs of local property document as the basis for budget allocation. Furthermore, budget documents that have been prepared from each accounting entity included in the Local Budget design section. In this process, it will involve the Local House of Representatives to discuss the draft Local Budget including the draft of capital expenditure budget and fixed asset.

\section{3) Output Generated}

Outputs resulting from the capital expenditure budgeting process and fixed assets and fixed assets are general goods needs plan for planning below and in 2016 which will be the basis for budgeting. Furthermore, for the output resulting from the capital expenditure budgeting process and fixed assets and fixed assets starting 2017 ie plans for the needs of local property which has accommodated the information needs of procurement and maintenance of each accounting entity.

\section{4) Proposed Operational Standards and Procedures}

Based on the analysis of the quality of information on the financial statements of The Provincial Government of East Nusa Tenggara from 2013-2016 which has been discussed previously, the results obtained that the quality of information has been sufficient to be a decision-making material. Therefore, in order to utilize the information of local government financial report, it is proposed a concrete form of how to use it through the making of SOP proposal. The draft SOP is intended for decision making especially in planning and budgeting of capital expenditure and fixed assets. In addition to being a real roadmap utilization of local government financial statement information, the draft SOP is intended to answer the needs of stakeholders planning decision-making and budgeting capital expenditures and fixed assets in accounting entity and the local finance management unit which until now has not had technical instructions business process planning and local property budgeting.

The proposed SOP design has been adapted to the sectoral regulatory framework in the area of fixed assets and the conditions and needs of The Provincial Government of East Nusa Tenggara. The sectoral regulatory framework is in accordance with the mandate of Government Regulation Number 27 Year 2014 Concerning the Management of State/Local Property and Ministerial Regulation Number 19 Year 2016 Concerning Guidelines for Management of Local Property. Adjustment of the conditions and needs of The Provincial Government of East Nusa Tenggara first seen from the form and authority of accounting entity, which is based on the delegation of authority from the Users of the Goods to the Power of Users of Goods. Second, the adjustment takes into account the conditions and needs of the local finance management unit as a Goods Administration Officer. Therefore, the SOP for the preparation of the proposed needs of the proposed local property includes SOP on the User Power of Goods, the Goods Users and the Goods Adminis-tration Officer. List of proposed SOPs for preparation of local needs planning, as follows: (1) SOP Draft of plan for the needs of local property Preparation by the Procuring User Authority; (2) SOP Review of plan for the needs of local property Design on User Power of Goods by Users of Goods; (3) SOP Drafting of plan for the needs of local property on Users of Goods; (4) SOP Design of plan for the needs of local property Review on Users of Goods by Goods Administration Officials; (5)SOP Drafting of plan for the needs of local property in Goods Administration Officials.

\section{CONCLUSION, LimitATION AND SUGGESTION}

\section{A. Conclusion}

Based on the results of the analysis of this study, three conclusions can be drawn. First, the quality of LGFS of The Provincial Government of East Nusa Tenggara for year 2013-2016 has a quality value of $82-85$ or $73.21 \%-75.89 \%$ or moderate. This means that on the four dimensions of measu-rement of the qualitative characteristics of financial statements, the 2013 - 2016 LGFS of The Provincial Govern-ment of East Nusa Tenggara is sufficient to be used as material for decision making. The results of the analysis also show that during the four reporting periods divided into the application of cash-based accounting standards to accruals in 2013-2014 there was an increase in the quality of information on LGFS when applying accrual-based accounting standards, although it is not significant because it is at the same quality level moderate.

Second, there are three efforts made to improve the quality of information on LGFS by The Provincial Government of East Nusa Tenggara, namely increasing commitment to accounting policies, increasing human resource capacity and improving information systems. Increased commitment to accounting policies is carried out by establishing local head regulations on accounting policies and accounting systems of the local government into Governor Regulation Number 21 concerning Accounting Policy and Governor Regulation Number 22 concerning Local Government Accounting Systems, which have been adjusted to accrual-based government accounting standards. Increasing the capacity of human resources is carried out by taking part in socialization and technical guidance carried out by the central government related to accounting and reporting to keep abreast of developments in local financial manage-ment regulations that can affect economic transactions/events in local governments. Improved information systems are carried out by increasing local financial management information system capacity so that it is expected that later reporting of fixed assets in the Board of Local Revenue, Financial and Asset Management can be done using local financial management information system support.

Third, in the framework of the design of utilizing LGFS information on budgeting for capital and fixed assets, it must pay attention to three related elements, namely the document used, the parties involved and the output produced. Documents used in accordance with the provisions of the legislation, namely plan for local fixed asset needs document contains the substance of planning the 
procurement and maintenance of local fixed asset. However, an important document that is not yet owned is the operational system procedure that regulates in detail the procedures for preparing the plan for local fixed asset needs. The parties involved in the planning of capital expenditure from the executive of the local government are the budget function in the work unit and the functions of the budget and asset managers in the Board of Local Revenue, Financial and Asset Management. Furthermore, when the capital expenditure budget is included in the draft of local government budget it will involve the Local House of Representatives in the discussion process. Thus, the LGFS information relating to budgeting for capital expenditure and fixed assets as well as the actual condition of fixed assets must be taken into consideration by the parties involved in the capital expenditure budgeting process. The result output is the proposed capital expenditure plan from the work unit and the proposed capital expenditure in the draft of local government budget allocated based on the plan for local fixed asset needs document. For this reason, the plan for local fixed asset needs preparation process must use information on fixed assets and depreciation in the LGFS. Based on these three elements, a draft utilization plan of local government financial information is prepared in the form of plan for local fixed asset needs Compilation SOP draft by Goods User Proxy, SOP for plan for local fixed asset needs Proposal Review on Property User Authorities by Goods Users, plan for local fixed asset needs Compilation SOP by Goods Users, SOP for plan for local fixed asset needs Proposal Review on Goods Users by the Goods Administration Officer and the plan for local fixed asset needs Compilation SOP by the Goods Administration Officer, as attached.

\section{B. Limitation}

This research has several weaknesses and limitations. First, this study attempts to combine reliable dimensions based on the Government of the Republic of Indonesia [3] with faithful representation dimensions according to Beest, Braam and Boelens [2], which means that not all elements of each dimension are the same, so there is a possibility of inaccuracy in the operationalization of qualitative characteristics. Second, this study measures the quality of LGFS limited to reporting entities only, has not involved the opinions of accounting entities that are obliged to prepare work unit financial statement as a consolidation material which will later be compiled into LGFS. Third, this study has not examined the extent of the role of internal control officers in guaranteeing the quality of information quality of LGFS. Fourth, this research was conducted in 2018 to measure the quality of the LGFS in 2013-2016, so that it was feared that there would be a mistake in filling out questionnaires by respondents. Fifth, the confirmation conducted does not involve external parties, it is feared that the information is not objective.

\section{Suggestion}

Based on the weaknesses and limitations, this research has several suggestions. First, to minimize the possibility of inaccuracy in the operationalization of qualitative characterristics, each indicator is advised to conduct interviews with the financial report compiler after the results of the questionnaire are obtained. Second, to measure the quality of information the LGFS needs to involve the work unit as an accounting entity. Third, it is necessary to review the extent of the role of the internal control apparatus in guaranteeing the quality of information on the quality of the LGFS. Fourth, to conduct research in order to evaluate the quality of information on LGFS it is necessary to do it directly in each of the reporting years to maintain the accuracy of the data from the questionnaire and confirmation results. Fifth, make a confirmation involving external parties of the regional government to ensure the objectivity of information obtained by involving external auditors or the community.

\section{REFERENCES}

[1] Government of The Republic of Indonesia. (2010). Government Regulation Number 71 of 2010 Concerning Government Accounting Standard. Jakarta: Government of Indonesia.P. Mauro, "Corruption and growth," Quart. J. Econ. 110 (3), pp. 681-712, 1995

[2] Beest, F. V., Braam, G., \& Boelens, S. (2009). Quality of financial reporting: measuring qualitative characteristics. Netherlands: Nijmegen Center for Economics (NiCe).

[3] Government of The Republic of Indonesia. (2014). Law Number 23 of 2014 concerning Local Government as last amended by Law Number 9 of 2015 concerning Amendment to Law Number 23 Year 2014 concerning Regional Government. Jakarta: Government of the Republic of Indonesia.P. Bardhan, "Corruption and development: A review of issues," J. Econ. Literature, vol. 35(3), pp. 1320-1346, 1997.

[4] Government of The Republic of Indonesia. (2003). Law Number 17 of 2003 Concerning State Finance. Jakarta: Government of Indonesia.

[5] Hyndman, N., \& Connolly, C. (2011). Accruals accounting in the public sector: A road not always taken. Management Accounting Research, 22(1), 36-45.

[6] Nogueira, S. P. S., Margarida F. Jorge, S., \& Cervera Oliver, M (2013). The usefulness of financial reporting for internal decisionmaking in Portuguese municipalities. Management Research: Journal of the Iberoamerican Academy of Management, 11(2), 178-212.

[7] Government of The Republic of Indonesia. (2005). Government Regulation Number 24 of 2005 Concerning Government Accounting Standard. Jakarta: Government of Indonesia.

[8] Carroll, D., A. \& Marlowe, J. (2009). "Is there a 'gaap gap'? a politico-economic model of municipal accounting policy", Journal of Public Budgeting, Accounting \& Financial Management, Vol. 21 Issue: 4, pp.501-523.

[9] Huda, A. M. (2017). Reconstruction of Transfer Systems to Regions in the Framework of Using Accrual Basis Using Contigency Model dan Soft Systems Methodology. Jakarta: University of Indonesia.

[10] Blondal, J. (2003). Accrual accounting and budgeting: key issues and recent developments. En: Gestión pública por resultados y programación plurianual: documentos presentados en la Primera Reunión de Responsables de Presupuesto de América Latina y el Caribe, Santiago, enero 2003-LC/L. 1949-P-2003-p. 27-38.

[11] Government of The Republic of Indonesia. (2006b). Government Regulation Number 8 of 2006 Concerning Financial and Performance Reporting of Government Institution. Jakarta: Government of Indonesia.

[12] International Public Sector Accounting Standards Board (IPSASB). (2014). The Conceptual Framework for General Purpose Financial Reporting by Public Sector Entities. IFAC.

[13] Lapsley, I. (1999). Accounting and the new public management: instruments of substantive efficiency or a rationalising modernity? Financial Accountability \& Management, 15(3 - 4), 201-207.

[14] Cohen, S., Kaimenaki, E., \& Zorgios, Y. (2007). How different are accrual accounting financial measures compared to cash accounting ones? Evidence from Greek Municipalities. In 6th Annual Conference of the Hellenic Accounting and Finance Association, Patra (pp. 14-15).

[15] Government of The Republic of Indonesia. (2004b). Law Number 15 of 2004 Concerning Audit of The Management \& Accountability of The State Finance. Jakarta: Government of Indonesia. 
[16] Pamungkas, B. (2018). Determinants of the Application of Full Accrual Basis to the Local Government. Accounting Journal, XXII (01), 68-85

[17] Hastowo, H. (2015). Information Quality Analysis of State General Treasurer Financial Statements. Jakarta: University of Indonesia.

[18] Purwohartono, D. (2015). Factors Affecting the Quality of Financial Statements of State Ministries / Agencies and Their Impacts on the Benefits of Financial Reporting. Jakarta: Universitas Indonesia.

[19] The Audit Board. (2014). The Audit Result Report of The Audit Board of Republic of Indonesia on East Nusa Tenggara Provincial Government Local Government Financial Statement Year 2013. Jakarta: The Audit Board.

[20] The Audit Board. (2015). The Audit Result Report of The Audit Board of Republic of Indonesia on East Nusa Tenggara Provincial Government Local Government Financial Statement Year 2014. Jakarta: The Audit Board.

[21] The Audit Board. (2016). The Audit Result Report of The Audit Board of Republic of Indonesia on East Nusa Tenggara Provincial Government Local Government Financial Statement Year 2015. Jakarta: The Audit Board.

[22] The Audit Board. (2017). The Audit Result Report of The Audit Board of Republic of Indonesia on East Nusa Tenggara Provincia Government Local Government Financial Statement Year 2016. Jakarta: The Audit Board.

[23] Jonas, G. J., \& Blanchet, J. (2000). Assessing quality of financial reporting. Accounting Horizons, 14(3), 353-363.

[24] Ariyani, U. (2016). Optimization Analysis of the Use of Information in Financial Statements in Decision Making for Planning and Budgeting for Capital Expenditures and Maintenance Expenditures (Case Study in the Ministry of Finance). Salemba: Universitas Indonesia.

[25] Alchian, A. A., \& Demsetz, H. (1972). Production, Information Costs, And Economic Organization. The American Economic Review, 62(5), 777-795.

[26] Jensen, M. C., \& Meckling, W. H. (1976). Theory of the firm: Managerial behavior, agency costs and ownership structure. Journal of financial economics, 3(4), 305-360.

[27] Clark, T. (2004). Theories of corporate governance: the philosophical foundations of corporate governance. London and New York: Routledge.

[28] Mardiasmo. (2009). Public Sector Accounting. Yogyakarta: Andi Offset.

[29] Government of The Republic of Indonesia. (2004a). Law Number 1 of 2004 Concerning State Treasury. Jakarta: Government of Indonesia.

[30] International Fund For Agricultural Development (IFAD). (1999). IFAD International Fund For Agricultural Development Executive Board - Sixty-Seventh Session, Good Governance: An Overview.

[31] Government of The Republic of Indonesia. (2006a). Law Number 15 of 2006 Concerning The Audit Board. Jakarta: Government of Indonesia.
[32] Government of The Republic of Indonesia. (2006a). Law Number 15 of 2006 Concerning The Audit Board. Jakarta: Government of Indonesia.

[33] Financial Accounting Standards Board (FASB). (2008). Statement of financial accounting concepts no. 2: qualitative characteristics of accounting information. Original Pronouncements as Amended.

[34] Nordiawan, D., \& Hertianti, A. (2010). Public Sector Accounting. Jakarta: Salemba Empat.

[35] Siregar, B. (2017). Public Sector Accounting. Yogyakarta: UPP STIM YPKN.

[36] International Public Sector Accounting Standards Board (IPSASB). (2016). Handbook of International Public Sector Accounting Pronouncements (2016 ed. Vol. I). IFAC.

[37] Miles, M. B., dan Huberman, A. M. (1984). Qualitative Data Analysis Second Edition. United States of America: SAGE Publications.

[38] Ministry of Home Affairs. (2013). Minister of Home Affairs Regulation Number 64 Year 2013 Concerning Application of Accrual-Based Government Accounting Standards to Local Government. Jakarta: Ministry of Home Affairs.

[39] The East Nusa Tenggara Provincial Government. (2014b). Governor Regulation of East Nusa Tenggara Province Number 21 of 2014 Concerning Accounting Policy of The East Nusa Tenggara Provincial Government. Kupang: The Provincial Government of East Nusa Tenggara.

[40] The East Nusa Tenggara Provincial Government. (2014c). Governor Regulation of East Nusa Tenggara Province Number 22 of 2014 Concerning Accounting System of The East Nusa Tenggara Provincial Government. Kupang: The Provincial Government of East Nusa Tenggara.J. G. Lambsdorff, "How Corruption Affects Persistent Capital Flows", Econ. Govern.," vol.4(3), pp. 229-244, 2003 b.

[41] International Accounting Standards Board (IASB). (2008). Exposure Draft of An Improved Conseptual Framework for Financial Reporting: Chapter 1: The Objective of Financial Reporting and Chapter 2: Qualitative Characteristics and Contstraints of DecisionUseful Financial Reporting Information.

[42] The East Nusa Tenggara Provincial Government. (2014a). Local Government Financial Statement Year 2013 (Audited). Kupang: The Provincial Government of East Nusa Tenggara.

[43] The East Nusa Tenggara Provincial Government. (2015). Local Government Financial Statement Year 2014 (Audited). Kupang: The Provincial Government of East Nusa Tenggara.

[44] The East Nusa Tenggara Provincial Government. (2016). Local Governmnt Financial Statement Year 2015 (Audited). Kupang: The Provincial Government of East Nusa Tenggara.

[45] The East Nusa Tenggara Provincial Government. (2017). Local Government Financial Statement Year 2016 (Audited). Kupang: The Provincial Government of East Nusa Tenggara. 